\title{
Оцінка доцільності симультанних лапароскопічних втручань при лікуванні жовчнокам'яної хвороби з хірургічною коморбідністю органів черевної порожнини
}

\begin{abstract}
Мета роботи: визначити та оцінити якість надання медичної допомоги хворим з жовчнокам’яною хворобою і коморбідною хірургічною патологією, використовуючи сучасні шкали для оцінки стану хірургічних хворих. Визначити оптимальну стратегію лікування для таких пацієнтів.

Матеріали і методи. На базі ВОКЛ ВІМДЛ проліковано 410 пацієнтів з поєднаною патологією, одна 3 яких хронічний калькульозний холецистит і 681 хворий з прооперованою лише однією хірургічною патологією органів черевної порожнини. Використано методику з нульовою гіпотезою, аналіз за Пірсоном, Тюкі, Манна-Уїтні.

Результати досліджень та їх обговорення. Симультанне хірургічне лікування більш доцільне і краще відповідає сучасним стандартам надання медичної допомоги. Стан пацієнтів після операцій значуще не відрізнявся в обох групах. Не було клінічно значущої різниці у термінах видужання. Рівень післяопераційних ускладнень у обох групах не відрізнявся. Морбідність у обох групах дорівнювала нулю. Симультанні операції не показали підвищення стресовості для організму пацієнта. Глікемія чи інші об'єктивні показники (лабораторні дані чи показники шкал для оцінки стану пацієнта) у хворих обох груп не мала значущих відхилень. Тривалість операцій і наркозу зросли, але це не спричинило збільшення анестезіологічних ризиків. Також тривалість госпіталізації значуще не зросла, а різниця не перевищила одного ліжко-дня. Якщо порівнювати з двома госпіталізаціями для двох операційних втручань, то перевага очевидна. Методика ефективна і показує свої переваги над конвенційними методами.
\end{abstract}

Ключові слова: жовчнокам'яна хвороба; ERAS; симультанні лапароскопічні втручання.

Постановка проблеми і аналіз останніх досліджень та публікацій. Сучасні дані дозволяють оцінити ураження дорослого населення жовчнокам'яною хворобою (ЖКХ). Показники досягаються 30 \%. Дані FDA, опубліковані у MedScape, підтверджують, що до 20 \% хворих у США мають вже діагностовану ЖКХ, 1-3 \% населення захворіє наступного року, у 500000 хворих ЖКХ ускладниться і стане причиною 10000 смертей, 7000 з них помре через прямі ускладнення гострого холециститу і холедохолітіазу $[1-4,10]$. Очікується, що 30 \% смертей внаслідок ускладнень ЖКХ будуть через рак жовчного міхура чи загальної жовчної протоки. Європейські дані тотожні $[5-7,15]$. Така епідеміологічна поширеність і небезпека ускладнень роблять дослідження цієї патології актуальними. Малоінвазивні методи як одна з важливих складових сучасної стратегії лікування ERAS роблять хірургічне операційне лікування не лише безпечним і легким для хворого, а й пріоритетним над консервативною чи конвенційною курацією пацієнта.

До 22 \% хворих на ЖКХ страждають від ЖКХ комбінованої з іншою хірургічною патологією. 74 \% із цих хворих мають патологію в межах черевної порожнини, 10-15 \% - це холедохолітіаз із холецистолітіазом [1].

Під час операції організм зазнає серйозний травматичний та ноцицептивний стрес, через що виділяється велика кількість медіаторів запалення, основними з яких для розвитку стрес-відповіді є ІЛ-6. У відповідь на це відбувається викид стресгормонів: АКТГ, альдостерон, кортизол, глюкагон, адреналін. Це допомагає організму стійко переносити зовнішні втручання та гарантувати йому видужання. Спочатку компенсаторний механізм зі збільшенням тривалості операції набирає патологічного, деструктивного характеру й провокує основні метаболічні, нейроендокринні і запальні зміни, що призводять до післяопераційної дисфункції органів і системи $[8,10,11]$, і є основною причиною післяопераційної летальності $[9,12,14,16]$. Корекція цих показників і зменшення травматизації і часу операції знижує рівень хірургічної стрес-відповіді і допомагає запобігти ускладненням при одночасному пришвидшенні видужання [13, 17].

Матеріали і методи. На базі Волинської обласної клінічної лікарні у відділенні інвазивних методів діагностики та лікування (ВОКЛ ВІМДЛ) було виконано 410 симультанних лапароскопічних операційних втручань для лікування ЖКХ та супутньої хірургічної патології органів черевної порожнини. Доступ виконували згідно з розробленими на базі Волинської обласної клінічної лікарні, у відділенні інвазивних методів діагностики та лікування, рекомендаціями зі встановлення портів і ергономіки операції (табл. 1). 
Таблиця 1. Характер симультанних лапароскопічних операційних втручань

\begin{tabular}{||l|c|c||}
\hline \multicolumn{1}{|||}{ Назва операційного втручання } & Кількість номінальна & Відсоток \\
\hline ЛХЕ+ЛКР фундоплікація за Тупе & 87 & 3,21 \\
\hline ЛХЕ+ТАРР & 15 & 1,21 \\
\hline ЛХЕ+пластика вентральної грижі & 5 & 0,24 \\
\hline ЛХЕ+пластика пупкової грижі & 1 & 0,24 \\
\hline ЛХЕ+вертикальна резекція шлунка & 1 & 0,98 \\
\hline ЛХЕ+геміколектомія & 4 & 1,21 \\
\hline ЛХЕ+адреналектомія & 5 & 9,51 \\
\hline ЛХЕ+новоутворення печінки (доброякісні) & 39 & 2,68 \\
\hline ЛХЕ+новоутворення підшлункової залози (доброякісні) & 11 & 8,78 \\
\hline ЛХЕ+адгезіолізис & 36 & 28,78 \\
\hline ЛХЕ+холедохолітотомія & 118 & 21,46 \\
\hline ЛХЕ+інтраопераційна холангіографія & 88 & 100 \\
\hline Загалом & 410 & \\
\hline \hline
\end{tabular}

Для об’єктивності і показовості дослідження пацієнтів оцінювали післяопераційно, перед випискою зі стаціонару, відповідно до шкал післяопераційної готовності до виписки (PT-RHDS), 3 використанням протоколів оцінки READI і оцінки очікуваних післяопераційних ускладнень, захворюваності і смертності P-POSSUM. Як і в попередніх дослідженнях наших колег в оцінці за READI задовільним вважався показник вище 7 балів, хорошим вище 9. Також для додаткової наглядності і широти дослідження використовували шкалу оцінки післяопераційних легеневих ускладнень ARISCAT. Завдяки цьому можна було оцінити i якість надання хірургічної медичної допомоги, відповідно до сучаних стандартів ERAS, адже показники, що використовуються у шкалі, необхідні для адекватного контролю виконання стандартів хірургії швидкого відновлення.

Більшість хворих складали жінки віком 45-60 років, з операційним ризиком за ASA 2 і однією супутньою патологією (табл. 2-5).

Для точної об'єктивної оцінки ефективності симультанних операційних втручань ми порівнювали дві групи хворих - I група - хворі, що перенесли лікування лише однієї хірургічної патології (681 хворий, якому виконали лапароскопічні холецистектомії, висікання пахової грижі, КСОД, адгезіолізис, холедохолітотомію, інтраопераційну холангіографію, операції з приводу новоутворень печінки, підшлункової залози, резекцію шлунка) і II група - хворі, що перенесли симультанне лапароскопічне операційне лікування ЖКХ та супутньої хірургічної патології (410 хворих). У групі хворих виконували лікування з проведенням операції за класичною лапароскопічною методикою, а II групі з проведенням операції за власною методикою. Для оцінки в нашому дослідженні використовували чіткі числові показники: тривалість операції в хвилинах, об'єм крововтрати, рівень глікемії, рівень кортизолу та альдостерону, сатурація кисню крові, рівень гемоглобіну, креатиніну. Показники збирали для використання їх у визначенні рівня хірургічної стрес-відповіді, а також для оцінки кардіологічної періопераційної захворюваності у хворих, що отримують не кардіоваскулярне операційне лікування, а також показники ризику респіраторних ускладнень у хворих у післяопераційному періоді. Рівень хірургічної стрес-відповіді перегукується з деякими аспектами шкал Lee та ARISCAT. Отримані результати вносились до бази даних Microsoft Office Excel 2010 (Microsoft Corp, США), опис кількісних ознак, на основі критерію Шапіро-Уілка, 3 визначенням середнього арифметичного (М) і стандартного відхилення (S). Для порівняння груп використовували критерії Мана-Уїтні, або U-критерій. При широкому порівняння використовувався метод ANOVA. Критичний рівень значущості $p$ у всіх розрахунках визначено як 0,05 . 
Таблиця 2. Характер операційних втручань за віком і статтю

\begin{tabular}{|c|c|c|c|c|c|c|c|c|}
\hline \multirow{3}{*}{ Назви операційних втручань } & \multicolumn{2}{|c|}{$25-44$} & \multicolumn{2}{|c|}{$45-60$} & \multicolumn{2}{|c|}{$60-75$} & \multicolumn{2}{|c|}{$75-90$} \\
\hline & \multicolumn{8}{|c|}{ Стать } \\
\hline & Ч & Ж & Ч & Ж & Ч & Ж & Ч & Ж \\
\hline ЛХЕ+ЛКР фундоплікація за Тупе & 6 & 6 & 11 & 32 & 4 & 25 & 1 & 2 \\
\hline ЛХЕ+ТАРР & 0 & 1 & 4 & 7 & 3 & 0 & 0 & 0 \\
\hline ЛХЕ+пластика вентральної грижі & 1 & 1 & 0 & 0 & 1 & 2 & 0 & 0 \\
\hline ЛХЕ+пластика пупкової грижі & 0 & 0 & 0 & 0 & 0 & 1 & 0 & 0 \\
\hline ЛХЕ+вертикальна резекція шлунка & 0 & 1 & 0 & 0 & 0 & 0 & 0 & 0 \\
\hline ЛХЕ+геміколектомія & 1 & 1 & 1 & 1 & 0 & 0 & 0 & 0 \\
\hline ЛХЕ+адреналектомія & 0 & 1 & 0 & 2 & 0 & 2 & 0 & 0 \\
\hline ЛХЕ+новоутворення печінки (доброякісні) & 4 & 2 & 7 & 7 & 6 & 10 & 2 & 1 \\
\hline $\begin{array}{l}\text { ЛХЕ+новоутворення підшлункової залози } \\
\text { (доброякісні) }\end{array}$ & 0 & 4 & 3 & 2 & 0 & 0 & 1 & 1 \\
\hline ЛХЕ+адгезіолізис & 2 & 5 & 7 & 11 & 4 & 5 & 0 & 2 \\
\hline ЛХЕ+холедохолітотомія & 2 & 14 & 9 & 18 & 15 & 31 & 12 & 17 \\
\hline ЛХЕ+інтраопераційна холангіографія & 11 & 17 & 12 & 21 & 5 & 14 & 1 & 7 \\
\hline
\end{tabular}

Таблиця 3. Ризик операційних втручань

\begin{tabular}{|c|c|c||}
\hline Ступінь & Кількість & Відсоток \\
\hline 1 & 9 & 2,2 \\
\hline 2 & 340 & 82,9 \\
\hline 3 & 61 & 14,9 \\
\hline
\end{tabular}

Таблиця 4. Ризик операційних втручань за віком

\begin{tabular}{|c|c|c|c|c||}
\hline \multirow{2}{*}{ Ступінь } & \multicolumn{3}{|c|}{ Вік, роки } \\
\cline { 2 - 5 } & $25-44$ & $44-60$ & $60-75$ & $75-90$ \\
\hline 1 & 4 & 5 & 0 & 0 \\
\hline 2 & 73 & 130 & 108 & 29 \\
\hline 3 & 3 & 20 & 20 & 18 \\
\hline
\end{tabular}

Таблиця 5. Об'єм операційних втручань за віком

\begin{tabular}{||c|c|c|c|c||}
\hline \hline \multirow{2}{*}{ Вікові групи } & \multicolumn{4}{|c||}{ Об’єм операційних втручань } \\
\cline { 2 - 5 } & низький & середній & великий & розширений \\
\hline $25-44$ & 0 & 62 & 16 & 2 \\
\hline $44-60$ & 0 & 106 & 47 & 2 \\
\hline $60-75$ & 0 & 94 & 34 & 0 \\
\hline $75-90$ & 0 & 39 & 7 & 1 \\
\hline \hline
\end{tabular}


Результати досліджень та їх обговорення. При ретельному ретроспективному аналізі історій хвороб було проаналізовано хірургічну оцінку хворих за шкалою P-POSSUM, де мінімальний і максимальний показник у двох груп відрізнявся ( 5/17 і 6/15 для першої і другої груп відповідно), але середній показник у обох групах був достатньо однорідним, і різницею можна було знехтувати (7,84 та 7,77 для першої і другої груп відповідно). Ці дані вказують на неупереджений добір до двох груп, який відбувався виключно за принципом хірургічної коморбідності.

При обробці операційних даних було виявлено збільшення часу операційного втручання. Загалом середній час операції в першій групі скла-

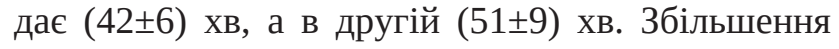
часу на $17 \%$ не приводить до будь-якого статистично значущого збільшення ускладнень під час чи після операції, а також не збільшує час відновлення хворого і сумарний час перебування у стаціонарі. Обидва показники знаходять в межах контрольованого наркозу та не перевищують 2 год в маргінальних значеннях, що не збільшує ризик респіраторних ускладнень після операції за шкалою ARISCAT. Сумарна крововтрата у мілілітрах не відрізнялась більш ніж на 5 мл і теж не мала статистичних наслідків. Рівень креатиніну сироватки на всіх етапах не перевищував 2 мг/дл, що не збільшувало ризик серцево-судинних подій як ускладнень операцій за шкалою Lee. Показники, які відповідали за рівень хірургічної стрес-відповіді, контролювались на різних етапах лікування включно операційний етап. Для курації хворих використовували протоколи ERAS для усіх пацієнтів. Контроль насичення вуглеводами хворих достатньою мірою допоміг запобігти суб'єктивному дискомфорту, а рівень глікемії лабараторно не відрізнявся і не потребував корекції інсуліном. Рівень глікемії має досить високу інформативність у передбаченні хірургічної стресреакції (рис. 1).

За критерій розвитку артеріальної гіпотензії було прийнято зниження середнього артеріального тиску на 30 \% від початкового або нижче 80 мм рт. ст. у систолічній фазі чи девіацію сегмента ST на ЕKГ. Тактика купірування гіпотензії була однаковою у всіх випадках і полягала у збільшенні темпу інфузії, збільшенні кількості колоїдів чи додавання пресорів. Після збору і підрахунку даних суттєвої різниці між середнім систолічним і діастолічним тиском протягом операції, яка могла б вплинути на ризики ускладнень, не виявлено (рис. 2).

Час операції - один з найважливіших показників ефективності методу, збільшувався несуттєво, і, відповідно, не призводить до збільшення рівня післяопераційних ускладнень. У свою чергу, сумарний час наркозу, включно період безопераційного наркозу (інтубація-екстубація), зріс відповідно незначно. Анестезіологічні ризики не збільшувались, відповідно пов'язані ускладнення зростали (рис. 3, 4).

Післяопераційні результати аналізували і для визначення доцільності, ефективності і безпеки симультанного підходу для лікування ЖКХ із супутньою хірургічною патологією аналізували готовність пацієнта до виписування зі стаціонару 3 2-го дня після операції. Готовність хворого до ви-

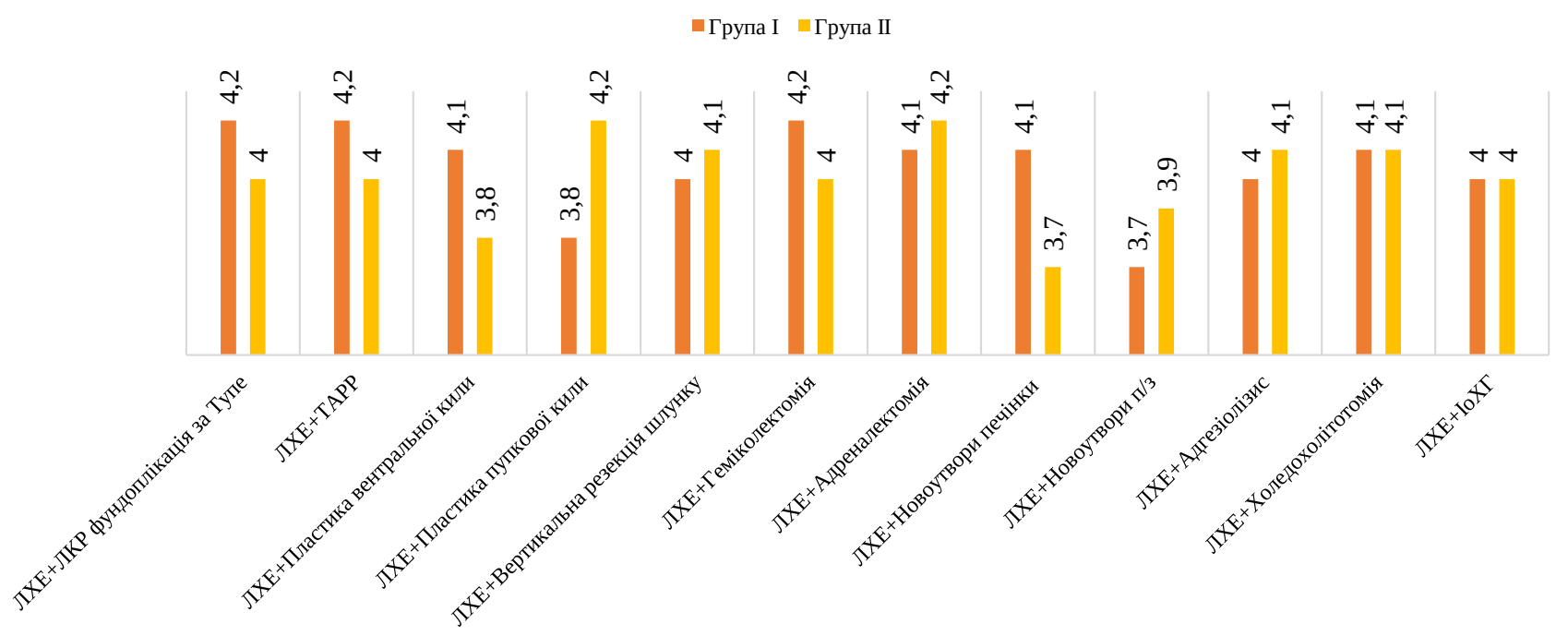

Рис. 1. Рівень глюкози у хворих I і II груп. 

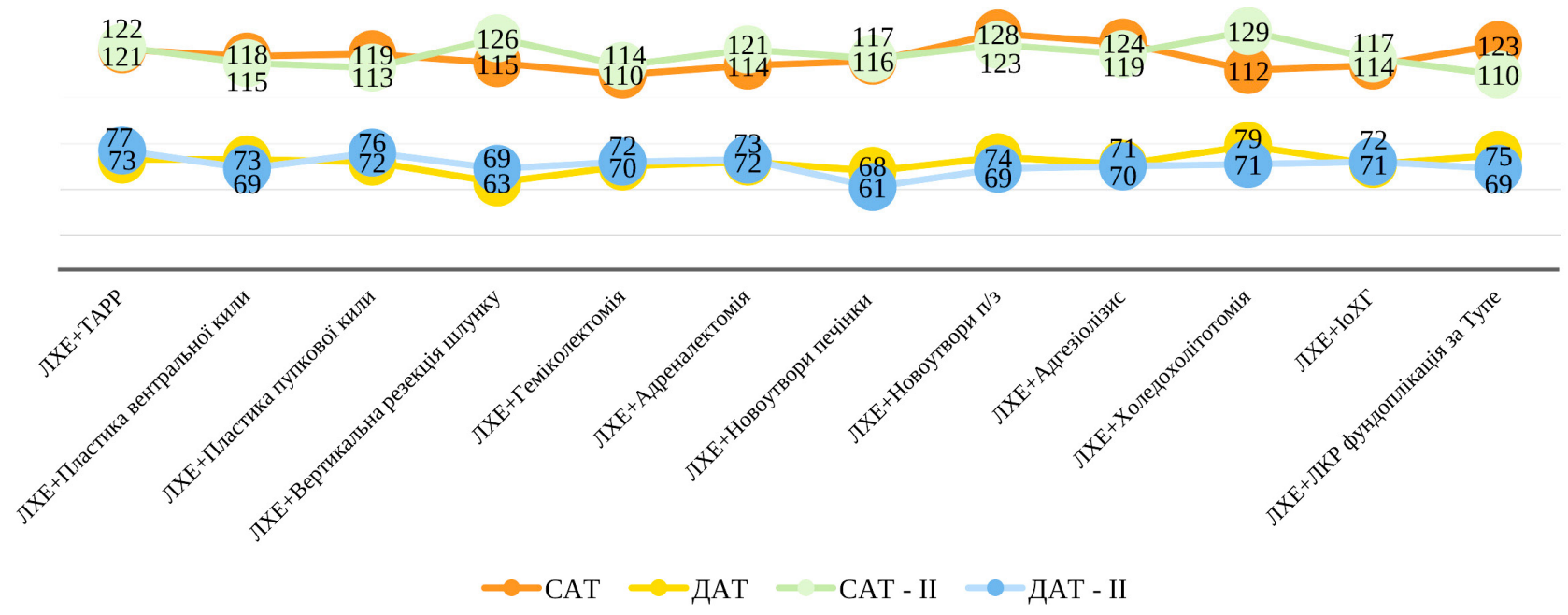

Рис. 2. Середній АТ під час операції.

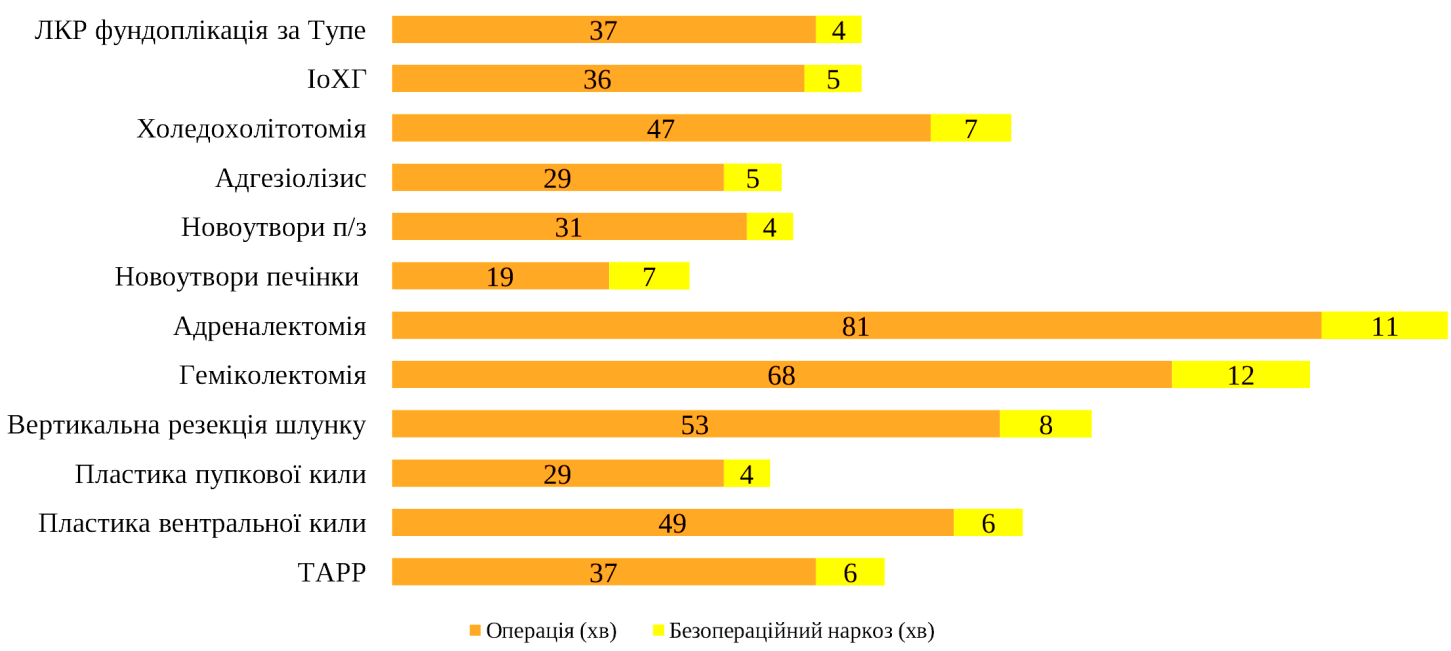

Рис. 3. Загальний час операції в I групі.

ЛХЕ+ЛКР фундоплікація за Тупе

$$
\text { ЛХЕ+IoXГ }
$$

ЛХЕ+Холедохолітотомія

ЛХЕ+Адгезіолізис

ЛХЕ+Новоутвори п/3

ЛХЕ + Новоутвори печінки

ЛХЕ+Адреналектомія

ЛХЕ+Геміколектомія

ЛХЕ+Вертикальна резекція шлунку

ЛХЕ+Пластика пупкової кили

ЛХЕ+Пластика вентральної кили

ЛХЕ+ТАРР
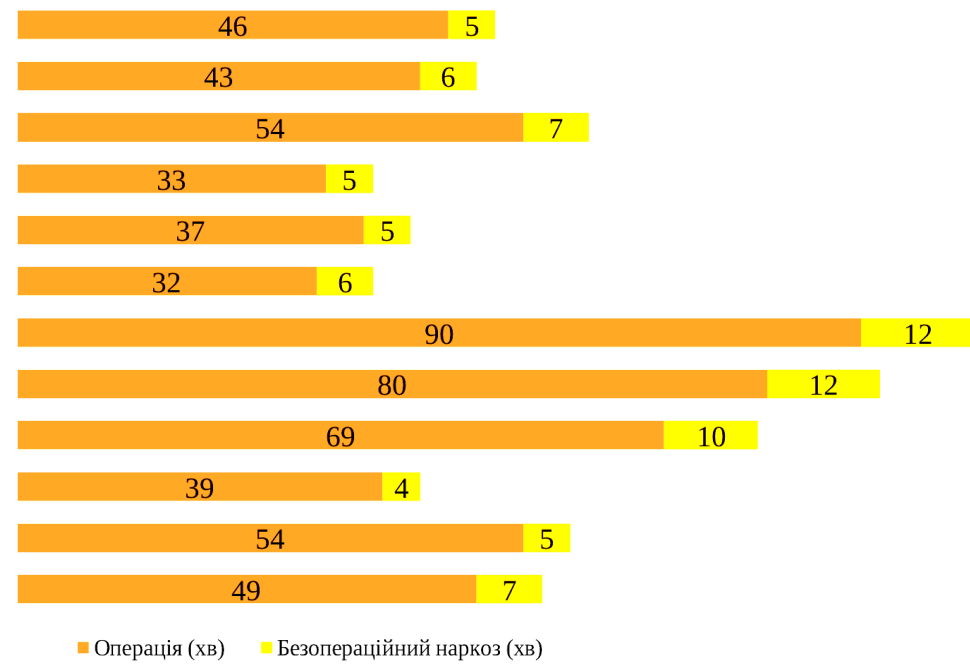

Рис. 4. Загальний час операції в II групі. 
писування визначалась об'єктивно із застосуванням форми PT-RHDS, з числовим вираженням, де менше 7-ми балів - незадовільно, 7 і вище - задовільно, хворий може залишити стаціонар, готовий до виписування, більше 9-ти - хороший, хворий повинен залишити стаціонар (рис. 5). Варто наголосити, що для ведення усіх хворих, а саме 681 хворого з виконаною однією операцією i 410 хворих із симультанним операційним лікуванням, з обох групах, ми використовували протоколи ERAS для покращення результатів і пришвидшення одужання, при чому об’єм реалізації протоколів в обох групах тотожний. Також лікарів підтримували і стимулювали раннє випису- вання пацієнтів за їхнім бажанням, при умові відсутності протипоказань до виписування, загрозливих станів, ускладнень та набиранням хворого не менше 7-ми балів READI. Така тактика виправдана міжнародними рекомендаціями ISS (міжнародною спілкою хірургів), які вперше опубліковані в JAMA в 2005 році та прийняті і запроваджені FDA та EMA. Також сучасні протоколи ERAS цілком підтримують цю точку зору, підтверджуючи зменшення післяопераційної захворюваності, смертності, недоцільних економічних витрат.

Якщо аналізувати дані у відсотковому співвідношенні, то отримаємо наступний результат, наведений на рисунку 6.

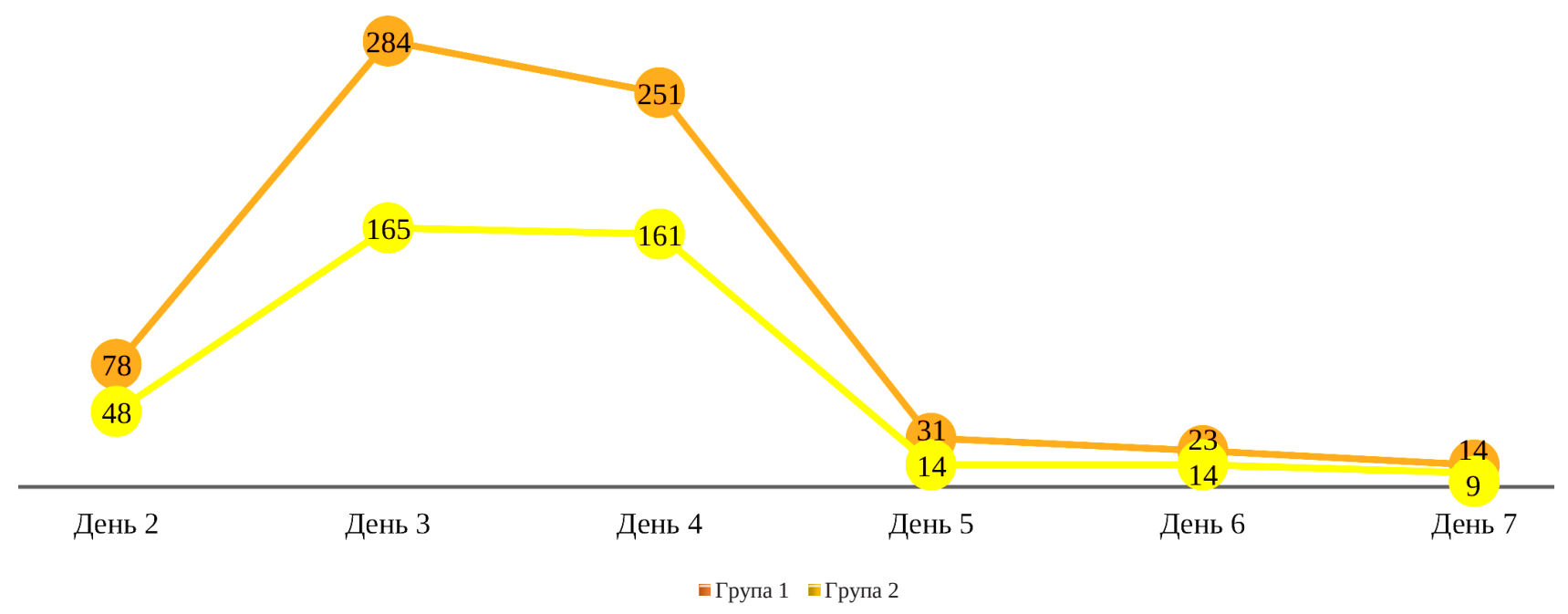

Рис. 5. День готовності пацієнта до виписування в групах I і II.

45

40

35

30

25

20

15

10

5

0

День 2

День 3

День 4

День 5

День 6

День 7

- Група 1 Ерупа 2

Рис. 6. День готовності пацієнта до виписування в I і II групах у відсотках. 
Отже, хоча в першій групі і спостерігається незначне збільшення тенденції до раннього виписування у перші 3 дні після операції, середній час до виписування відрізняється несуттєво (3,53 і 3,54 дні відповідно). Зважаючи на значне збільшення ризиків післяопераційної захворюваності у пацієнтів з кожним наступним днем перебування у стаціонарі, а також економічною недоцільністю затримки хворих, ці дані є красномовними, і можуть бути використані у повсякденній хірургічній практиці. Також зауважимо, що одноетапне хірургічне лікування дає можливість пацієнту уникнути повторної госпіталізації для лікування супутньої хірургічної патології, а також від додаткової операції, перебування у стаціонарі та пов’язані $з$ цими факторами ризики та економічні втрати.

Висновки. 1. Хірургічна стрес-відповідь - головна причина післяопераційних анестезіологічних ускладнень і летальності. Зменшення вираз-

\section{СПИСОК ЛІТЕРАТУРИ}

1. Validation of patient and nurse short forms of readability for hospital discharge scale and their relationship to return to hospital / Marianne E. Weiss, Linda L. Costa, Olga Yakusheva, Kathleen L. Bobay // Health Serv. Res. - 2014. - Vol. 49 (1). P. 304-317.

2. Effects of indomethacin on endocrine responses and nitrogen loss after surgery / T. Asoh, C. Shirasaka, I. Uchido [et al.] // Ann. Surg. - 1987. - Vol. 206. - P. 770-776.

3. Smith R. Depth of anesthesia with desflu-rane does not influence the endocrine-methabolic response to pelvic surgery / R. Smith, A. Kee, S. Barrat // Acta Anaesth. Scand. - 2008. Vol. 52. - P. 99-105.

4. Multimodal analgesia and intravenous nutrition preserves total body protein following major upper gastrointestinal surgery / B. Beilin, F. Martin, Y. Shavit // Reg. Anesth. Pain Med. - 2002. - Vol. 27. - P. 15-22.

5. Beilin B. Supression of natural killer cell activity by high-dose narcotic anesthesia in rats / B. Beilin, H. Bessler, E. Mayburd // Brain Behave Immun. - 1989. - Vol. 3. - P. 129-137.

6. Bent J. Effects of preemptive analgesia on pain and cytokine production in the postoperative period / J. Bent, J. Paterson, K. Mashiter // Anesthesiology. - 2003. - Vol. 98. - P. 151-155.

7. Bromage P. Effects of high-dose fentanyl anaesthesia on the established metabolic and endocrine re-sponse to surgery / P. Bromage, H. Shibata // Anaesthesia. - 1978. - Vol. 39. - P. 19-23. 8. Continuous epidural blockade arrests of postoperative decrease in muscle protein fractional synthetic rate in surgical patients / D. Halliday, J. Cassuto, P. Nellgard, L. Stage // Anesthesiology. 1997. - Vol. 86. - P. 1033-1040.

9. Desborough J. The role of neuroinflammation and neuroimmune activation in persistent pain / J. Desborough, G. Hall // Pain. 2001. - Vol. 90. - P. 1-6. ності стрес-відповіді завжди призводить до швидшої реконвалесценції.

Виконання симультанних операційних втручань з приводу ЖКХ та супутньої хірургічної патології органів черевної порожнини не призводить до збільшення основних показників хірургічної стресвідповіді та не збільшує періопераційні ризики.

Симультанні лапароскопічні операції - ефективний і безпечний спосіб лікування, що має низку позитивних моментів не лише з боку об’єктивних числових показників, а й суб'єктивно для кожного пацієнта є привабливішим, і відповідає сучасним вимогам надання якісної медичної допомоги.

Метод встановлення портів та забезпечення ергономіки, розроблений на базі Волинської обласної клінічної лікарні у відділенні інвазивних методів діагностики та лікування, забезпечує несуттєву, статистично незначущу відмінність основних показників з показниками групи хворих, що перенесли лише одну операцію.

10. Desborough J. Modification of the hormonal and metabolic response to surgery by narcotics and general anes-thesia / J. Desborough // Clin. Anaesthesiol. - 1989. - Vol. 3. - P. 317334.

11. Garlick P. The stress response to trauma and surgery / P. Garlick, H. Burns, R. Palmer // Br. J. Anaesth. - 2000. Vol. 85. - P. 109-117.

12. Kehlet $H$. The stress response to surgery: release mechanism and the role of pain relief / H. Kehlet // Acta Chir. Scand. - 2006. - Suppl. 55. - P. 22.

13. Kehlet H. Multimodal approach to control postoperative pathophysiology and rehabilitation / H. Kehlet // Br. J. Anaesth. -1997. - Vol. 78. - P. 606-617.

14. Kehlet H. Modification of responses to surgery by neural blockade: clinical implications / H. Kehlet, D. Wilmore. - In: M. Cousins, P. Bridenbaugh (eds.) Neural blockade in clinical anesthesia and management of pain. Philadelphia, PA: Lippincott, 1998. - P. 129-175.

15. Surgical patients' experience of readiness for hospital discharge and perceived quality of discharge teaching in acute care hospitals. - Access mode: https://www.researchgate.net/ publication/329954189_Surgical_Patients'_Experiences_of_ Readiness_for_Hospital_Discharge_and_Perceived_Quality_of_ Discharge_Teaching_in_Acute_Care_Hospitals

16. Effect of implementing discharge readiness assessment in adult medical-surgical units on a 30-day return to hospital. The READI Randomized Clinical Trial / Marianne E. Weiss, Olga Yakusheva, Kathleen L. Bobay [et al.] // JAMA Netw Open. 2019. - Vol. 2 (1). - P. 187-387.

17. Perceived readiness for hospital discharge in adult medicalsurgical patients / M. Weiss, L. Piacentine, L. Lokken [et al.] // Clin. Nurse Spec. - 2007. - Vol. 21 (1). - P. 31-42 


\section{REFERENCES}

1. Marianne, E. Weiss, Linda, L, Costa, Olga Yakusheva, \& Kathleen, L. Bobay (2014). Validation of patient and nurse short forms of readability for hospital discharge scale and their relationship to return to hospital. Health Serv. Res., 49 (1), 304317.

2. Asoh, T., Shirasaka, C., Uchido, I., Baldini G., Bagry H., \& Carli F. (1987). Effects of indomethacin on endocrine responses and nitrogen loss after surgery. Ann. Surg., 206, 770-776.

3. Smith, R., Kee, A., \& Barrat S. (2008). Depth of anesthesia with desflu-rane does not influence the endocrine-methabolic response to pelvic surgery. Acta Anaesth. Scand., 52, 99-105. 4. Beilin, B., Martin, F., \& Shavit, Y. (2002). Multimodal analgesia and intravenous nutrition preserves total body protein following major upper gastrointestinal surgery. Reg. Anesth. Pain Med., 27, 15-22.

5. Beilin, B., Bessler,„H., \& Mayburd, E. (1989). Supression of natural killer cell activity by high-dose narcotic anesthesia in rats. Brain Behave Immun., 3, 129-137.

6. Bent, J., Paterson, J., \& Mashiter, K. (2003). Effects of preemptive analgesia on pain and cytokine production in the postoperative period. Anesthesiology, 98, 151-155.

7. Bromage, P., \& Shibata, H. (1978). Effects of high-dose fentanyl anaesthesia on the established metabolic and endocrine re-sponse to surgery. Anaesthesia, 39, 19-23.

8. Halliday, D., Cassuto, J., Nellgard, P., \& Stage, L. (1997). Continuous epidural blockade arrests of postoperative decrease in muscle protein fractional synthetic rate in surgical patients. Anesthesiology, 86, 1033-1040.

9. Desborough, J., \& Hall, G. (2001). The role of neuroinflammation and neuroimmune activation in persistent pain. Pain, 90, 1-6.
10. Desborough, J. (1989). Modification of the hormonal and metabolic response to surgery by narcotics and general anes-thesia. Clin. Anaesthesiol., 3, 317-334.

11. Garlick, P., Burns, H., \& Palmer, R. (2000). The stress response to trauma and surgery. Br. J. Anaesth., 85, 109-117.

12. Kehlet, H. (2006). The stress response to surgery: release mechanism and the role of pain relief. Acta Chir. Scand., (55), 22. 13. Kehlet, H. (1997). Multimodal approach to control postoperative pathophysiology and rehabilitation. Br. J. Anaesth., 78, 606-617.

14. Kehlet, H., \& Wilmore, D. (1998). Modification of responses to surgery by neural blockade: clinical implications. Neural blockade in clinical anesthesia and management of pain. Cousins, M., \& Bridenbaugh, P. (Eds.). Philadelphia, PA: Lippincott.

15. Surgical patients' experience of readiness for hospital discharge and perceived quality of discharge teaching in acute care hospitals https://www.researchgate.net/publication/329954189_Surgical_ Patients'_Experiences_of_Readiness_for_Hospital_Discharge_ and_Perceived_Quality_of_Discharge_Teaching_in_Acute_ Care_Hospitals

16. Marianne, E. Weiss, Olga Yakusheva, Kathleen L. Bobay, Linda Costa, Ronda G. Hughes (2019). Effect of implementing discharge readiness assessment in adult medical-surgical units on a 30-day return to hospital. The READI Randomized Clinical Trial. JAMA Netw Open. 2 (1), e187387. doi: 10.1001 / jamanetworkopen.2018.7387.

17. Weiss, M., Piacentine, L., Lokken, L., Ancona, J., Archer, J., Gresser, S., Holmes, S., Toman, S., Toy, A., \& Vega-Stromberg T. (2007). Perceived readiness for hospital discharge in adult medical-surgical patients. Clin. Nurse Spec., 21 (1), 31-42.

Отримано 05.09.2019

Електронна адреса для листування: vodoo.lsmu@gmail.com.

M. M. HALEI ${ }^{1}$, I. YA. DZUBANOVSKIJ ${ }^{2}$, I. P. MARCHUK ${ }^{1}$, P. A. GASHCHYSHYN ${ }^{1}$

Volyn Regional Clinical Hospital ${ }^{1}$

I. Horbachevsky Ternopil National Medical University ${ }^{2}$

\title{
ASSESSMENT OF FEASIBILITY OF SIMULTANEOUS LAPAROSCOPIC INTERVENTIONS IN THE TREATMENT OF CHOLELITHIASIS WITH SURGICAL ABDOMINAL COMORBIDITY
}

\begin{abstract}
The aim of the work: to determine and evaluate the quality of medical care for patients with gallstone disease and comorbid surgical pathology, using modern scales of evaluation of the status for surgical patients to decide which strategy of treatment is the best for these patients.

Materials and Methods. 410 patients who were treated surgically in Volyn Regional Clinical Hospital in the Department of Invasive Diagnosis and Treatment with combined pathology and 681 patients who were treated surgically with only one surgical pathology. Null hypothesis technique used, Pearson analysis, Tukey, Mann-Whitney.

Results and Discussion. Simultaneous surgical treatment is more appropriate and better meets current standards of care. Patients' condition after surgery did not differ significantly in both groups. Also, there were no clinically significant difference in terms of recovery. Morbidity in both groups was null. Simultaneous operations haven’t shown up any rise of stress for patients' body. There were no significant difference in glycaemia or any other objective data (laboratory data, or data of scales assessing the patients condition) in both groups of patients. There were no dramatical rising of the duration of operation and general anesthesia also this rising didn $t$ lead to bigger perioperative risks. The difference of intrahospital stay between both groups had no significant odds, and the difference was no more than one bed-day. Especially if compared with two different hospitalization for two different operations. The technique is effective and shows its advantages over conventional methods.
\end{abstract}

Key words: gallstone disease; ERAS; simultaneous; surgery; laparoscopy. 
Н. М. ГАЛЕЙ ${ }^{1}$, И. Я. ДЗЮБАНОВСКИЙ ${ }^{2}$ И. П. МАРЧУК ${ }^{1}$, П. А. ГАЩИШИН ${ }^{1}$

Волынская областная клиническая больница ${ }^{1}$

Тернопольский национальный медицинский университет имени И. Я. Горбачевского МОз Украины²

\title{
ОЦЕНКА ЦЕЛЕСООБРАЗНОСТИ СИМУЛЬТАННЫХ ЛАПАРОСКОПИЧЕСКИХ ВМЕШАТЕЛЬСТВ ПРИ ЛЕЧЕНИИ ЖЕЛЧНОКАМЕННОЙ БОЛЕЗНИ С ХИРУРГИЧЕСКОЙ КОМОРБИДНОСТЫЮ ОРГАНОВ БРЮШНОЙ ПОЛОСТИ
}

\begin{abstract}
Цель работы: определить и оценить качество оказания медицинской помощи больным с желчнокаменной болезнью и коморбидной хирургической патологией используя современные шкалы для оценки состояния хирургических больных. Определить оптимальную стратегию лечения для таких больных.

Материалы и методы. На базе ВОКБ ОИМДЛ прооперированых 410 пациентов с сочетанной патологией и 681 прооперированных больных с только одной хирургической патологией органов брюшной полости. Использовали методику с нулевой гипотезой, анализ по Пирсону, Тюки, Манна-Уитни.

Результаты исследований и их обсуждение. Симультанное хирургическое лечение более целесообразно и лучше соответствует современным стандартам оказания медицинской помощи. Состояние пациентов после операций не отличаеться в обеих группах значимо. Не было клинически значимой разницы в сроках лечения. Уровень послеоперационных осложнений не отличался у обеих групп. Морбидность в обеих группах также была нулевой. Симультанные операции не показали повышения стрессовости для организма. Гликемия или другие объективные показатели (лабораторные данные или показатели шкал для оценки состояния пациента) у больных обеих групп не имели значительных отличий. Продолжительность операций и наркоза выросли, но это не несло повышения анестезиологических рисков. Также продолжительность госпитализации не повысилась значительно, а разница не превышала одного койко-дня. Если сравнивать с двумя госпитализациями для двух операций, то преимущество очевидно. Методика эффективна и показывает свои преимущества над конвенционными методами.
\end{abstract}

Ключевые слова: желчнокаменная болезнь; ERAS; симультанные лапароскопические вмешательства. 